\title{
Physical assessment and motor skills development on a group of students from rural areas
}

\author{
Ionuţ ONOSE ${ }^{1}$, Raluca Mihaela HODORCĂ ${ }^{2}$, Cristina-Elena MORARU ${ }^{3}$, Adriana ALBU ${ }^{4}$
}

\begin{abstract}
Growth and development are processes characterizing in the early years of a person. There are some differences in the evolution of these two processes dependent on the sex of the person and the family of origin. Material and Methods: The study was conducted on a sample of 81 students of 5th class coming from two villages in Botosani County. It was assessed physical development (using national reference values) and motor skills (number of elements) from scoring scales. The study was conducted on two different communities and sex. Processing of the results was performed using Pearson Test. Results and Discussion: height dominant values are average (49.38\%), calculated on communities and sex differences were not statistically significant. Weight most frequently average (49.38\%), not statistically significant differences calculated. Diagnosis of physical development highlights the existence of harmony in $54.32 \%$ cases. The maximum vote on pushups appears only in $17.28 \%$ cases. Differences calculated on sex are statistically significant at $p<0.01\left(f=3, \chi^{2}=8.001\right)$ and indicate that there are quicker progress of female students in which puberty occurs earlier and is accompanied by better motor skills. Conclusions: In interpreting the results of students in sports trials should consider a number of factors and not just one.
\end{abstract}

Key words: physical development, physical exercise, motor skills

\section{Rezumat}

Creşterea şi dezvoltarea sunt procese care particularizează primii ani de viaţă ai unei persoane. Există o serie de diferenţe legate de evoluţia acestor două procese dependente de sexul persoanei şi de mediul de provenienţă al familiei. Material şi metode: studiul s-a realizat pe un lot de 81 elevi din clasa a Va proveniţi din două sate din judeţul Botoşani. A fost apreciată dezvoltarea fizică (cu ajutorul valorilor de referinţă naţionale) şi abilităţile motrice (număr de flotări) pornind de la baremurile de notare. Studiul s-a realizat diferit pe cele două colectivităţi şi pe sex. Prelucrarea rezultatelor a fost realizată cu ajutorul testului Pearson. Rezultate şi discuţii: valorile dominante ale înălţimii sunt medii (49,38\%), diferenţele calculate pe colectivităţi şi sex fiind nesemnificative statistic. Greutatea se încadrează cel mai frecvent la valori medii (49,38\%), diferenţele calculate fiind tot nesemnificative statistic. Diagnosticul de dezvoltare fizică evidenţiază existența armoniei în $54,32 \%$ cazuri. La proba de flotări nivelul corespunzător notei 10 apare doar în 17,28\% cazuri. Diferenţele calculate pe sex sunt semnificative statistic la un $p<0.01\left(f=3, \chi^{2}=8.001\right)$ şi evidenţiază existenţa unei evoluţii mai rapide a elevilor de sex feminin la care pubertatea apare mai precoce, fiind însoţită şi de o evoluţie mai bună a abilităţilor motrice. Concluzii: în interpretarea rezultatelor obţinute de elevi la probele sportive trebuie să se ia în considerare un complex de factori şi nu unul singur.

Cuvinte cheie: dezvoltare fizică, exerciţiu fizic, capacitate motrică

${ }^{1}$ Assist.Prof., "AlexandruIoanCuza" University of Iasi, Romania, Faculty of Physical Education and Sport

${ }^{2}$ Assist.Prof., "Alexandru Ioan Cuza" University of Iasi, Romania, Faculty of Physical Education and Sport, e-mail:raluca.hodorca@yahoo.com

${ }^{3}$ Assoc.Prof., "AlexandruloanCuza" University of Iasi, Romania, Faculty of Physical Education and Sport

${ }^{4}$ Assoc.Prof., "Grigore T. Popa" University of Medicine and Pharmacy, Iași, Romania 


\section{Introduction}

Growth and development of the human body are two processes characteristic of the first period of life, known as the stage of evolution. From birth to adulthood body undergoes many changes that are influenced by several internal and external factors. In the category of internal factors enter genetics, while in the category of external factors enter geo-climatic conditions, nutrition, origin of the family, its socio-economic, housing and physical activity [1]. Family environment supplied from urban/rural greatly influences the physical development of children. Physical development of students in urban areas is much higher than that of children in rural areas. It is now a worldwide phenomenon with the exception of young people in the United States and those of Australia. What are the factors involved is not known certainly suspected the better nutrition, living conditions are different, some medical care more careful, have a more sustained education. Differences exist and require the realization of referencepoints differentiated by the origin of the environment [2]. Physical activity is a major contributing factor to maintaining the health of young people, to ensure balanced growth and development. Exercise taken systematically contribute to a better heart and breathing, the smooth development of the osteoarticular and muscular system, the general regulation of metabolism of the body [3]. Educational programs shall be implemented consistent with the child is facing the movement towards a permanent and balanced physical activity. During school physical activity should be carefully dosed in order not to exceed the capacity of the body's effort. In this regard they have been made scoring scales, scales that have positive and negative effects. Some students do not meet the scales and then prefer to exempt to not hurt the average, which is a mistake that could have negative effects on health. We have to find a better solution that is youth-oriented movement, but have no repercussions on the environment if not face a sustained physical effort [4].

\section{Study objectives}

Knowing the physical development of students in rural areas; Comparative evaluation of the communities and sex; diagnostic assessment of physical development on communities and on sex; evaluation of the students to fit in the sample floating scales, the assessment is made on the community, and sex.

\section{Material and methods}

The study was conducted on a sample of 81 students in the 5 th grade from two villages in Botosani County. 41 students were examined at the "Octav Băncilă" School, from Corni Village and 40 students from the "Anastasie Başotă" School, from Pomîrla Village. Students examined were aged between 10 and 12 years essential to assess the moment when the first pubertal changes. Sex, were examined throughout the group 33 boys (40.74\%) and 48 girls (59.25\%). In these young people were assessed motor skills and physical development. Motor skills are evaluated based on the number of push-ups performed and framing this issue in grading scales. To avoid great dispersion of results we will consider the following: under 5 , between 5 6, between 7-9, 10 (maximum) votes.

Physical development is studied from national reference values. They are made by measuring a statistically significant group of students in our country. Calculate the mean value and standard deviation are obtained by means of which sigmatic intervals. The reference values are differentiated depending on the age, sex and the origin of the family. Indicators studied are height and weight. Between the mean +/- sigma levels are considered average, the average between the +sigma and +2 sigma are large and very large than the average +2 sigma. At the opposite end is placed between the average values - sigma and average - 2 sigma indicates a low level, and the below average - 2 sigma a very low level. Values less than the average - lower than - 3 sigma and over +3 sigma of the average are pathological indicating gigantism and dwarfism for the height, and for the body weight malnutrition or obesity [5]. The correlation between height and body weight provides the diagnosis of physical development. If the two individual parameters are placed in similar sigmatic development is harmonic intervals. If they are placed in different sigmatic intervals disharmonic development with plus or minus weight. Statistical

Volume 10^Issue 19» 2017 
processing of the results was made using the Pearson Test.

\section{Results}

The discussion will be addressed in two main directions represented by the motor activity evaluated by the number of push-executed and the physical development of the students examined (body height and weight). The number of pushups corresponding 10 vote is currently only $17.28 \%$ of students examined, which is very little considering the area of origin of the students examined. In most cases $(49.38 \%)$ students grades $7-9$ vote. $4.93 \%$ attention rural youth who are not required number of push-ups to get even vote 5 . It is a surprising result for rural students who make frequent exercise in family households (Figure 1).

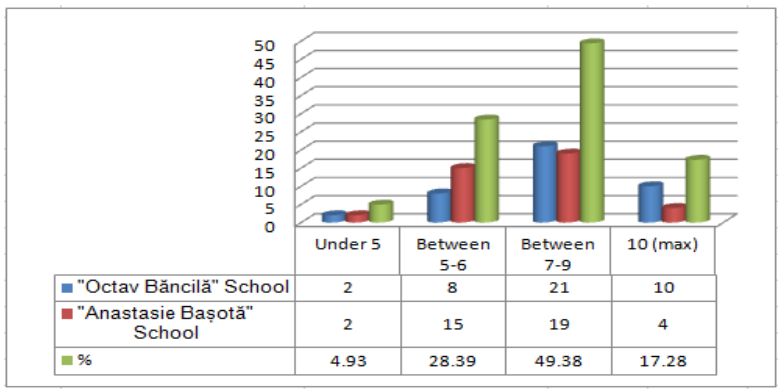

Figure 1 - Marks obtained by students according to the number of pushups performed

Grades below 5 appear to students of both communities, such that the calculated differences are not statistically significant $\left(p>0.05, f=3, \chi^{2}=\right.$ 4.718). Particular attention should be paid to performance during the pushups by gender. Obviously the female scale is different, but we are concerned on what sex occurs most frequently failures (very small number of pushups performed). In males there are students not performing the proper push-ups for the minimum 5 mark, while in women there are no such cases (Figure 2).

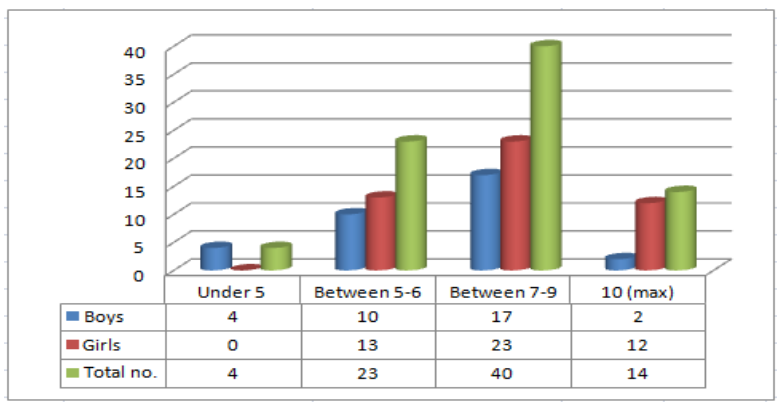

Figure 2 - Marks obtained by students in sample pushups, by gender

The differences obtained are statistically significant at $\mathrm{p}<0.05$ ( $\mathrm{f}=3 \chi^{2}=8.001$ ) and draw attention to male students, which do not meet all expectations. This situation is closely observed because the results depend on changes at the onset of puberty in both sexes. Physical development is evaluated by assessing the height and body weight.

There are other parameters that should be followed, but the national reference values are made only for these indicators. Benchmarks allow objectifying results and their correct interpretation.

The height of the pupils are placed mainly at the average values $(49.38 \%)$ what is a positive result. Attention on $2.46 \%$ students with pathological values for height, falling to a level higher than the average +3 sigma (Table I).

Table I- Framing height of students in sigmatic classes

\begin{tabular}{|c|c|c|c|c|}
\hline & $\begin{array}{c}\text { Mean } \\
\text { values }\end{array}$ & $\begin{array}{c}\text { Big } \\
\text { value } \\
\mathbf{S}\end{array}$ & $\begin{array}{l}\text { Very big } \\
\text { values }\end{array}$ & $\begin{array}{c}\text { Pathological } \\
\text { values }\end{array}$ \\
\hline \multicolumn{5}{|l|}{ Schools } \\
\hline $\begin{array}{c}\text { 1-"Octav } \\
\text { Băncilă" } \\
\text { School }\end{array}$ & 23 & 13 & 5 & 0 \\
\hline $\begin{array}{c}\text { 2-"Anastasie } \\
\text { Bașotă" School }\end{array}$ & 17 & 11 & 10 & 2 \\
\hline \multicolumn{5}{|l|}{ Sex } \\
\hline Boys & 16 & 13 & 4 & 0 \\
\hline Girls & 24 & 11 & 11 & 2 \\
\hline Total no. & 40 & 24 & 15 & 2 \\
\hline$\%$ & 49.38 & 29.62 & 18.51 & 2.46 \\
\hline
\end{tabular}

Significant differences are calculated on the collectivity ( $p>0.05, f=3, \chi^{2}=4.231$ ) and there was an similar evolution of the pupils of the two communities studied. 
Calculated on sex differences are all statistically significant ( $p>0.05, f=3, \chi^{2}=4.337$ ), which is more difficult to understand because on the girls appeared pubertal growth spurt while in the boys didn't.

The body weight is within a particular level (49.38\%) or higher (29.62\%). 11.11\% students drag attention with pathological values in weight. These values should be carefully monitored in order to detect the cause of this phenomenon (Table II). It may be a growth spurt or an evolutionary trend toward obesity.

Table II - Frame weight in sigmatic classes

\begin{tabular}{|l|c|c|c|c|}
\hline & $\begin{array}{c}\text { Mean } \\
\text { values }\end{array}$ & $\begin{array}{c}\text { Big } \\
\text { values }\end{array}$ & $\begin{array}{c}\text { Very } \\
\text { big } \\
\text { values }\end{array}$ & $\begin{array}{c}\text { Patho- } \\
\text { logical } \\
\text { values }\end{array}$ \\
\hline Schools & 26 & 10 & 3 & 2 \\
\hline $\begin{array}{c}\text { 1-"Octav } \\
\text { Băncilă" } \\
\text { School }\end{array}$ & 14 & 14 & 5 & 7 \\
\hline $\begin{array}{c}\text { 2-"Anastasie } \\
\text { Bașotă" } \\
\text { School }\end{array}$ & 14 & 10 & 4 & 5 \\
\hline Sex & 14 & 14 & 4 & 4 \\
\hline Boys & 26 & 14 & 9 \\
\hline Girls & 40 & 24 & 8 & $\mathbf{1 1 . 1 1}$ \\
\hline Total no. & $\mathbf{4 9 . 3 8}$ & $\mathbf{2 9 . 6 2}$ & $\mathbf{9 . 8 7}$ & \\
\hline \% &
\end{tabular}

Calculated differences are not statistically significant ( $p>0.05, f=3, \chi^{2}=7.602$ ) and also demonstrate that a similar evolution of the body weight of the children studied in the two schools. On all group and sex we calculated differences that are statistically insignificant $\left(p>0.05, f=3, \chi^{2}=\right.$ 1.579) which needs to be closely followed by teachers and doctors in the two communes.

The most important aspect is the correlation that should exist between height and weight of a student. Ideally, the two indicators are placed in the same sigmatic range, leading to the diagnosis of harmonic development. 54.32\% of children harmoniously developed is appropriate because the age of 10-12 years there is frequently leaps of growth that favor the diagnosis of disharmonic development. Such a diagnosis is present in 33.32\% of examined students.

Disharmonious development dominate situations with less weight (18.51\%) and not the development disharmonious with extra weight (14.81\%). It is an issue to be pursued because the media insist only on the risk of obesity neglecting cases of malnutrition.

$12.34 \%$ of young people draw the attention with pathological development, the height or the weight is placed above the average +3 sigma values.

These students just need to be watched, to see what is happening and to intervene if necessary (Table III). Significant differences are calculated on the collectivity ( $p>0.05, f=3, \chi^{2}=5.430$ ) phenomenon easily to understood and explained.

There are two villages in the same county where the economic situation of families is similar. They produce almost the same food, land productivity is similar. The grow in the household about the same animal, population have practically similar habits.

Table III - Diagnosis of physical development of students in the study group

\begin{tabular}{|c|c|c|c|c|c|c|}
\hline \multirow{2}{*}{ Diagnostic } & \multicolumn{2}{|c|}{ School } & \multicolumn{2}{|c|}{ Sex } & \multirow{2}{*}{$\begin{array}{l}\text { To } \\
\text { tal }\end{array}$} & \multirow{2}{*}{$\%$} \\
\hline & 1 & 2 & Boys & Girls & & \\
\hline Harmonious & 25 & 19 & 15 & 29 & 44 & 54.32 \\
\hline $\begin{array}{c}\text { Dis } \\
\text { harmonious } \\
\text { with - weight }\end{array}$ & 9 & 6 & 5 & 10 & 15 & 18.51 \\
\hline $\begin{array}{c}\text { Dis } \\
\text { harmonious } \\
\text { with + weight }\end{array}$ & 5 & 7 & 8 & 4 & 12 & 14.81 \\
\hline Pathological & 2 & 8 & 5 & 5 & 10 & 12.34 \\
\hline
\end{tabular}

Calculated on sex differences are not statistically significant ( $p>0.05, f=3, \chi^{2}=4.749$ ), which is hard to understand while there is growing leaps different in the two sexes.

\section{Discussions}

In interpreting the results we must start from the general principles of growth and development, known as the laws of growth. 5 laws of growth were set represented: growth rate decreases with age; growth is not uniform; the growth organs and tissuesis different for the same period of time; tissue and organ development is closely related to other organs and tissues; evolution is different according to the sex [6].

In interpreting the results obtained in this paper we insist on two laws of growth, that growth is not uniform and is different in the two sexes.

Growth is not uniform, but alternates. Alternating periods of growth in length with the increase in 
thickness, such that the percentage of students $50 \%$ develop harmonic is easy to understand. There are times when the student grows in height and it is long and thin followed by periods in thickness, it becomes fatty for a certain period of time. Also, we are not worried about students with pathological values because they are often transient, appearing only because of a growth spurt. However, they should be carefully monitored, requiring therapeutic intervention at the first sign of the disease evolution. If students fatter we cannot ask ourselves diets, but only increase the time for exercise and intensity with which it is executed.

The second law important for our study is related to the development in different sexes. The boys permanently have a higher growth than girls, except for the period between 10 and 12 years, when in girls appear first pubertal changes [7]. Pubertal changes in boys first appear from the age of 12 years, while girls from 10 years. In this context, the results divided by sex are difficult to understand, to range in different sigmatic classes of height and weight. Girls show sudden increase so that separation could be expected in different sigmatic classes compared to boys. Similar results were obtained in other studies conducted in Moldova area with students from 5th grade. Students must still carefully watch those, which is a problem because network medical school is becoming less developed. In rural areas, monitoring should be performed by the family doctor, aspect that is a big problem [8].

Another important element is related to the use of reference values, which allow us to highlight the population represented by two phenomena: the development of different environment urban/rural and accelerated growth $[9,10]$. The accelerated growth is a phenomenon highlighted by systematic measurements (from 7 to 7 years) and leads to the following idea: present values for height and weight are much higher compared to 40-50 years ago. It is a phenomenon that can not be detected using the body mass index [11]. Also, using body mass index can not reveal inappropriate developments, to a pathological phenomenon, especially for height.

Differences obtained in women on physical activity are understandable from the age at which girls have already appeared first pubertal changes. Puberty is a complex process in which all functions of the body improves, and hence the exercise capacity. The boys are still in its infancy (up to 12 years) had sometimes less developed motor skills. It is however an interesting result for rural students are often required in the household, participating frequently in working the fields. In a study conducted in rural Moldova all results are different because $31.7 \%$ boys make an intense physical activity and only $11.1 \%$ girls. Also, $19.3 \%$ of young people are not interested in movement and exercise [12].

\section{Conclusions}

Evaluation and interpretation of physical development of children and youth must be done carefully because growth jumps can be misunderstood. In children and young people can not question the recommendation diets because dietary restriction has negative consequences for growth and development process. Vigorous exercise helps to maintain health, such it is becoming less reliable, even in rural areas. Exercise capacity depends on the stage of development of puberty, an element that should be considered, especially when it comes to students who practice sports.

\section{References}

1. Sonenstein F. (2014).Introducing well being of adolescents in vulnerabile environment study: methods and findings, Journal of Adolescent health, 55;S1-S3.

2.Majuru A. (2016).Igiena școlară între norme și realități, Antropologie și sănătate, București: Ed.Academiei Române.

3.Alexander R. (2010).Children, their world, their education, London, New York:Ed.Routledge.

4. Bublitz M., Rhodes J. (2016).Activity in the classroom: interventions to increase activity and help fight childhood obesity, Journal of Childhood Obesity, vol.1, Issue 2.

5. Bardov V.G. (2009).Hygiene and ecology, Vinnytsya: NOVA KNYHA publishers.

6. Gavăt V., Albu A., Petrariu F.D. (2006).Alimentația și mediul de viață în relație cu dezvoltarea copiilor și tinerilor, Iași: Ed. "Gr.T.Popa ".

7. Natsuaki M.N. (2013).Puberty in context: toward a more nuanced understanding of early maturation, Journal of Adolescent health;53;677-678.

8. Onose I., Hodorca R. M., Albu A. (2016).Assessement of anthropometric indicators among rural students in the West of Moldavia,The European Proceedings of Social and Behavioural Sciences; vol.XI; 266-272.

9.Albu A., Rada C. (2014).The dynamics of authropological markers among roumanian teenagers between 1978-1999, 
Annuaire Roumanian d'Antropologie, Ed. Academiei Române, vol.51,65-72.

10. World Health Organisation (2007).WHO child groth standards,Geneva.

11. Crăciun D.M., Găitan R. (2017).Screening and prophilaxis in children from urban and rural environment:6-12 year old, Young Scientist, nr.3.1(43.1), 12-15.

12. Țigănaș O., Zepca V., Zaporojan A. (2015).Implicarea elevilor claselor gimnaziale și liceale în activitatea motrică, Anthropological Researches and Studies; nr.5; 28-33 